\title{
The Inscriptions of the Construction and Recovery Works of the Public Buildings and Utilities in Aquincum
}

\author{
Zsuzsanna Emília Kiss ${ }^{1 *}$ \\ 1 Department of History of Architecture and Monument Preservation, Faculty of Architecture, Budapest University of Technology \\ and Economics, H-1111 Budapest, 3 Műegyetem rkp., Hungary \\ * Corresponding author, e-mail: kisszsuem@eptort.bme.hu
}

Received: 07 May 2020, Accepted: 30 August 2020, Published online: 27 November 2020

\begin{abstract}
Inscriptions related to buildings and structures provide an important contribution when studying the architecture of Aquincum. They may also reveal the date of construction or improvement works and the identity of the builder. Occasionally, the indication can also provide the reason and purpose of the construction activity. The builder may be an individual or a definite group. As an individual, the name refers to a person's origin. If their role and position in the life of the city are also mentioned, the composition and identity of the urban elite can also be inferred. The identification of the different groups can contribute to an understanding of which religious, social, and other organisations operated in Aquincum. Both private construction and state-owned existed alongside each other. The date and location of the inscribed stones on the buildings refer to the prestige of Aquincum as the seat of governors. This article presents the information based on a detailed analysis of the captions found so far. A map showing the original texts and their location is attached to the article. In addition, a summary table covering the most significant information of the thirty inscriptions examined (dedication of the inscription, type of building/structure, nature of construction, reason for construction activity, nature of financial coverage, time of construction of the builder, construction board) are published.
\end{abstract}

Keywords

Aquincum, epigraphia, constructional inscription, Roman architecture

1 Introduction - inscriptions of sacred buildings related to the cult of Nemesis

The inscriptions on the public buildings of Aquincum are examined by grouping them according to the function of the particular building. For example, the inscriptions on the sacred buildings; most of which are related to the cult of Nemesis.

Such is the case with the fanum (fanum, -i n. sanctuary, sacred area) that was later added to the western gate of the amphitheatre at the military city (Póczy, 2004:p.111). Two inscribed altar stones (Cat. 1, Cat. 2) related to its construction were found at the same place, next to the southern wall of the sanctuary (Kuzsinszky, 1891:p.119). On both, the inscriptions are fragmentary. However, it is not a renovation, but a so-called - a solo - construction of a new facility. Unfortunately, these inscriptions give no information about when this happened or the date of this construction. The earliest date related to the Temple of Nemesis is on a votive altar (Cat. 3). This altar stone, $1.2 \mathrm{~m}$ high and $0.43 \mathrm{~m}$ wide, is decorated with a volute and a rose and was found in the back wall of the cell of the Nemesis sanctuary by Károly Torma (Kuzsinszky, 1891:p.117; Torma, 1881). From the date of the consuls - Rustico II et Aquilin(o) [co(n)s(ulibus)] - and according to the data - XII k(alendas) sept(embres) - in the text, the erection of the altar can be dated to Aug. 21, 162 AD. The founder of the altar stone was designed by Marcus Ulpius Zosimus, who, according to Károly Torma, was also the builder of the fanum. The evidence is visible in a small compass on the sanctuary. According to his argument, the sanctuary was made solely to hold the votive altar stone (Torma, 1881:p.63).

The inscription on the renovation of the Nemesis Temple, dating back to 1876 on Snail Hill (Csiga-domb), in Aquincum, next to the amphitheatre of the civil town, is also accurate (Cat. 4).

The almost complete and well-written inscription reveals all the important details of the renovation. Consequently, it is known that the temple was destroyed because of its poor condition: vetustate [con] lapsum. According to the date 
of the consul, [Messalla] et Sabi(no) co(n)s(ulibus) - and the date indicated in the text - VIII K(alendas) Iul(ias) the date of the inscription is Jun. 24, 214 AD. The restorers were Florus and Mercator duumvir quinquennials, and the offerer dedicans - or the curans, the supervisor of the works - was Aurelius Surus. According to his name, it is presumed that he was of Syrian origin.

The term "salariarius" in the inscription might be controversial because of its various interpretations. It could be that Aurelius Surus was honoured for his work or simply came from the city of Sala (Zalalövö). According to Bálint Kuzsinszky, Salariarius is a soldier who receives salary instead of a regular military mercenary, probably because he resigned his military service after his dismissal (Kuzsinszky, 1891:p.156). The discovery of a sarcophagus from Aquincum (CIL III 10501), on which the term salarius also appears, clearly indicates that the soldier in question, Titus Aelius Iustus, was a solitary soldier. In addition, if Aurelius Surus was of Sala origin, his name would likely include domo Sala, as in the case Mursa's Flavia Paula sarcophagus (Németh, 1999:p.59).

Another inscription about a later renovation was found under the ruins of the chapel (Cat. 5). The square limestone slab, $59 \mathrm{~cm}$ high and $58.5 \mathrm{~cm}$ wide, with a simple frame, was originally intended to be walled in the sanctuary wall. Similarly, to the previous examples, the date on which the table was set was Jun. 27, 259 AD. There is an interesting phenomenon in the dedication of the inscription, Deae Dianae Nemesi Aug(ustae), which proves that the figure of Nemesis and Diana became almost the same.

With the previous Nemesis inscriptions, the idea presents itself that they probably do not refer to the same building, as the first and second mentions fanum, while the fourth mentions temple. According to Károly Torma, the building to the right of the western gate of the amphitheatre was a Nemesis fanum or sanctuary, and the Nemesis temple was 29.4 meters west of the gate (Torma, 1881) (Fig. 1, Table 1).

\section{Inscriptions of sacred buildings related to the cult of other gods}

There is only one inscription left on sacred structures for the other gods. Such is the inscription on the construction of the temple erected to the goddess Dea Syria and Baltis (Cat. 6). Baltis and Dea Syria - on the inscription referred to as Diasuria - were Syrian goddesses whose reverence had conquered Pannonia at the same time. Therefore, it was possible to build a common temple (Kuzsinszky, 1937:pp.141-142).

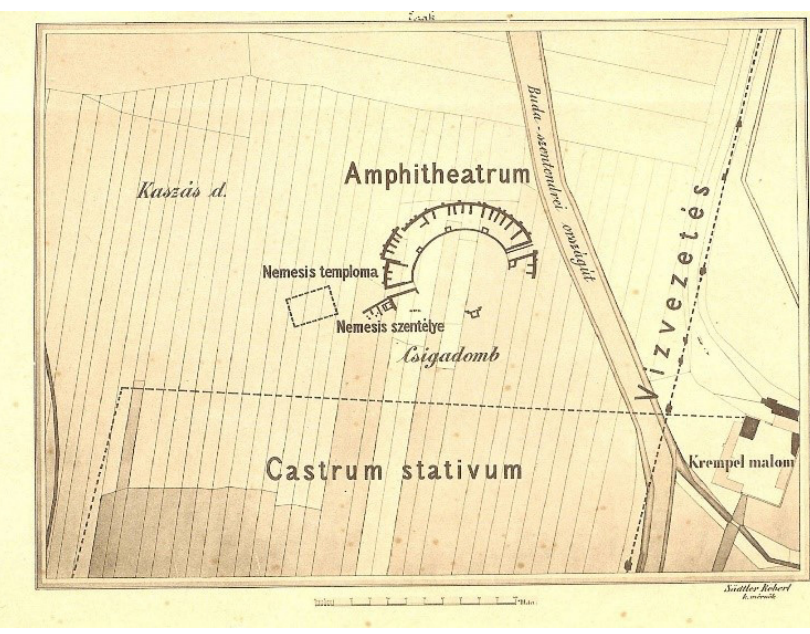

Fig. 1 The military town amphitheatre with the Nemesis Temple and the presumed site of the Nemesis Temple (Torma, 1881).

In the short inscription dated to the $3^{\text {rd }}$ century, neither the time of construction nor the reason is given, only the name of the builder - T(itus) Fl(avius) - is known.

In contrast, the constructional inscription on the Temple of Hercules answers almost all questions (Cat. 7 (a), Cat. 7 (b)). Before the analysis of the inscription, it is worth mentioning that the appearance and then strong presence of the cult of Hercules in Pannonia is related to the Severus Dynasty. Hence why, besides the birthplace of Septimius Severus in Africa, Hercules has one of the most widespread cults in Pannonia. The fragmentary building board found in 1974 is an especially important proof of this (Bánosi, 1984:p.44).

It turns out that the temples offered for the salvation of Marcus Aurelius, Antoninus Caracalla and his mother, Iulia Domna, were the target of major construction activities: fundamentis adie[cto portico] (Cat. 7 (a)) and fundamentis adie[cta (?) Porticu (?) ex voto fecit] (Cat. 7 (b)). Although the construction started from the groundwork, the description is not about constructing a new building, but about renovating, expanding and building a porticus. According to György Bánosi's supplement, the term [vetust(ate) conlapsum restituit] refers to this, since it even determines the reason for the restoration (Bánosi, 1984). Expansion may be evidenced by the terms adiecta or adiecto. The last line of the consul's name reveals that the construction was in $216 \mathrm{AD}$. What the text on the board does not answer is who or what body did the work as a votive act. György Bánosi analysed the possible constructors. He saw an opportunity that it might have been a member of the Legion's officers, perhaps the governor of the $216^{\text {th }}$ year, Octavius Appius Suetrius Sabinus, who is also 
known to have set up an altar to Hercules of Amphissa, in Aquincum. He also did not reject the possibility that one of the members of the body of troops in Aquincum might have been the builder (Bánosi, 1984:p.50). This inscription is also significant because it is the only one found to date in Pannonia that relates to the construction of the Temple of Hercules, and is one of the proofs of the reconstruction period following the Marcomannic Wars (AD 166-180).

We must note here, that in Aquincum and in its surroundings, the worship of the indigenous gods - in many cases identifying them to Roman gods - was very current. This is evidenced by altar stones inscriptions (Gabler, 1967:p.195).

The renovation of the Iuppiter Dolichenus Temple, which was also inscribed (Cat. 8), happened in this major rebuilding period, indicating that Septimius Severus and his son, who visited Aquincum in $202 \mathrm{AD}$, had rebuilt the Iuppiter Dolichenus Temple, which was a vetustate conlapsum, like the Hercules Temple. The names of the emperors in nominative case on the inscriptions of public buildings do not imply that the construction was ordered by the emperor personally. However, in this case, the reason might be that the renovation of the temples was not the duty of the state. By doing so, the ruler and his son were probably trying to encourage construction by the noblemen of the city, because at that time public money was primarily used to strengthen the borders (Szilágyi, 1956:p.14).

Similarly, to the temples of Hercules and Iuppiter Dolichenus, the Sanctuary of the Legio II Adutrix Pia Fidelis Severiana Valetudinarium is one of the renovations of sacred buildings in the military town. The plaque (Cat. 9), which records the construction of the building, cannot be dated precisely, it can only be stated that it was made during Severus Alexander's reign, between $222 \mathrm{AD}$ and $235 \mathrm{AD}$. It is interesting to note that this is not a simple temple, but a multi-purpose building with a bedroom or perhaps an infirmary and a portico.

There is also an inscription on the renovation of a temple for an unknown deity (Cat. 10). Although the inscription found in the second half of the $19^{\text {th }}$ century and first recorded by Macko (Fröhlich, 1891:p.162), is only four lines, it contains several interesting facts. The text was probably deliberately divided so that each line contained important information about the renovation of the temple, possibly similar to the large boards currently displayed on construction sites. The first line, which contains the name of the contributor, is engraved with much larger letters than the other three. He, C(aius) Cornel(ius) Corinthus, was of Greek descent by name. The reason for the offering can be read in the second line, which is nothing more than being elected as Augustalis (members of a religious, social group). Unfortunately, the inscription tells us nothing about the construction of the temple, but it turns out that the temple was splendidissimo, that is, it was nicely restored by C(aius) Cornel(ius) Corinthus. The release of the fourth line - PEP II - is debated. Róbert Fröhlich reads iterum [r]e[f(ecit)?] (Fröhlich, 1891). This is interesting because he puts the $P E P$ in the published original text (Fig. 2) in the [r]e[f(ecit)?] as if there was an unreadable letter before and after $\mathrm{E}$, and did not comment as to why he chose this solution. It is conceivable that the Greek origin of the offeror suggested by his name may have been spelt here - P instead of R for R and PH - or it may be a mistake of the illiterate engraver. János Szilágyi resolved the same as rep(aravit) (Szilágyi, 1956:p.106), which does not change the meaning of the text. Thus, Caius Cornelius Corinthus would have rebuilt the temple for the second time. It would be interesting to know why the temple had to be renovated twice within one generation.

The inscription documenting the construction of the Nymphaeum (Cat. 11) is partially a transition between sacred and profane buildings. This building, which adorns one of the squares of the city, was built and financed by city councillor, Caius Titius Antonius. It is important to record his name because he also funded other buildings of Aquincum. Any architectural remains associated with the inscription have not yet been discovered (Szilágyi, 1956:p.33). The nymphaeum structure may not have been significantly expensive, but that it is aquam induxit, or water was led to it, probably meant that an offset to the nymphaeum was built from the parent branch of the aqueduct.

\section{The case of the baths}

The first case of the profane buildings is the group of baths. Fifteen of this building group have been excavated in the area of Aquincum (Fröhlich, 1891:p.162). One of them was the balneum of the military town, the slab of which was found

\section{$C \cdot$ CORNEL· CORINTHVS O B AVGVSTALITATEM SPLENDIDISSIMO $\cdot$ TEMPLN II · PEP}

Fig. 2 Renovation inscription of Caius Cornelius Corinthus. (Cat. 10; Fröhlich, 1891:p.162) 
under the plaster of house No. 5 at Kolosy Square (Cat. 12). The stone slab in the notched frame, the letters painted red (Kuzsinszky, 1904:p.164), was probably inserted into the wall of the balneum. The name of Flavius Marcianus, who was a consul during his bath work at Severus Alexander, is not on the list of consuls. This suggests that he was a consul suffectus (Kuzsinszky, 1904:p.165). The third line of the inscription is missing, but it can be readily supplemented because it was a continuation of the name Severus Alexander, struck with the damnatio memoriae ("condemnation of memory"), which had begun in the previous line. The expression "solo" in the fourth row clearly shows that this is new construction; nevertheless, Margit Németh interprets it as a reconstruction (Németh, 1999:p.64). This military town bath was located in the north-eastern region of the canabae (the town, which surrounds the Roman camp). Although the constructional plaque had been placed in the stone vault of the Aquincum Museum in 1901, the bath itself - probably linked to this inscription - was only found during the excavations of the 1970s. During the excavation, various shaped pools, traces of the heating system, as well as water pipes and sewers were exposed (Póczy, 1983:p.269). It turned out that when the spa was installed, they adapted to the existing utility system and connected the spa's sewers to the northern main drainage channel from the northeast corner of the camp to the Danube.

The same installation principle can be observed in the larger bath of the legionary fortress, the exploration of which was begun in 1778 by István Schönvisner. At that time, walls and a hypocaust room were discovered, which he thought was a public bath. This hypothesis was confirmed by the inscription stone found in 1849, documenting the restoration of the bath (Cat. 13; Kaba, 1984:p.181). The inscription dated Jun. 30, 268 AD, is engraved on an altar stone, the traces of which are original and have been erased due to the new text in the first line of the new inscription. András Alföldi reconstructed the text, which was hardly readable on the very badly preserved stone in many places, using and modifying the supplement of Mommsen and Domaszewski (Alföldi, 1943:p.39). The text reveals that it was a major renovation, remodelling and perhaps extension because the bath had long been abandoned and unused (magno tempore in/[te]rmissas et destitutas), which was probably the result of the Marcomanni wars. During the reconstruction work begun in the Septimius Severus era, only 268 baths took place. It is also noteworthy that although there was a Gothic invasion of the Balkans in the summer of $268 \mathrm{AD}$, Aquincum was at peace and renovation works on the spa were able to continue (Alföldi, 1943:p.41). We have more information about the persons on the caption. The name Clementius Silvinus/Silvius, first mentioned in the title, can be found on two other Aquincum titles (CIL III 3424, CIL III 10424). Clementius Silvinus was a vir egregius, or knightly man, who, by order of Gallienus, dated 260 AD, came to the praeses, or civilian court. Aurelius Frontinus, who later became a dux or provincial military commander, had a similar career.

Although the first excavation of the bath dates back more than two centuries, its aqueduct and canal, which is perpendicular to the north-south main line, in a south-west direction, and its palaestra (parade-ground for different sports) were discovered only in the second half of the $20^{\text {th }}$ century.

A palaestra was discovered in the civil town as far back as 1884. In the palaestra, Károly Torma found several fragments (Fig. 3 (a) of a Greek dipinti (painted) inscription (Cat. 14). Although they are not closely related to the subject, because of their peculiarity and they have decorated a public building, they are worthy of mention. Due to the deeper location of the room compared to the surrounding rooms and some of the painted signs, Torma mistakenly concluded that there might have been a lupanarium (brothel) (B. Thomas, 1955:p.94). The misunderstanding was clarified by Mihály Kuzsinszky, who, in 1889, compiled the fragments in the correct order and interpreted some of them. He was able to spell out several words, including the term $\pi \alpha \dot{\lambda} \alpha \iota \sigma \tau \rho \alpha$ (palaestra) for the room's purpose. From the compilation of four lines of text (Fig. 3 (b)), he concluded that the inscription recorded the award of some men in the palaestra (Kuzsinszky, 1889:pp.120-124).

\section{The case of amphitheatres}

In the case of profane buildings in Aquincum, the largest number of inscriptions regarding construction activities are related to amphitheatres. The military city amphitheatre was previously mentioned in the paragraphs of the Nemesis sanctuaries, to which its wall was directly linked. A construction inscription was found in front of the northern entrance of the amphitheatre (Cat. 15). The $94 \mathrm{~cm}$ high, $172 \mathrm{~cm}$ long and $27 \mathrm{~cm}$ thick stone slabs have the text in a tabula ansata (tablet with handles). The tablet is held on two sides by a winged Victoria figure, and below it is a Pegasus, which was the coat of arms of the Legio II Adiutrix. The inscription dated $145 \mathrm{AD}$, is likely to be the construction inscription of the amphitheatre (Kuzsinszky, 1934:pp.180-181). However, this is not 


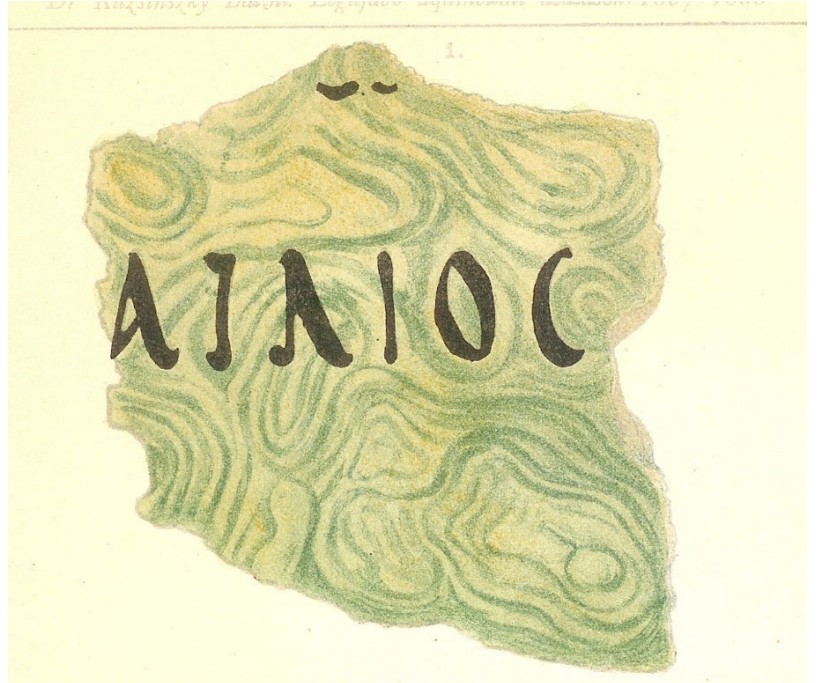

(a)

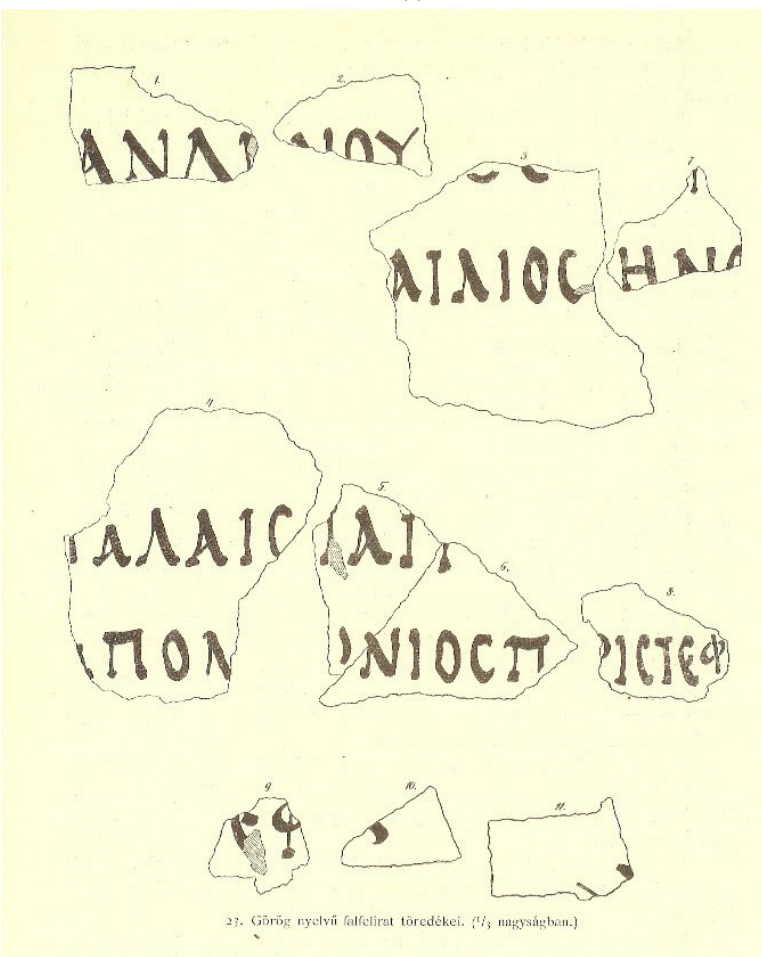

(b)

Fig. 3 (a) Fragment of the dipinti inscription on the palaestra. (Cat. 14) (Kuzsinszky, 1891:p.121); (b) Dipinti inscription fragments compiled by Bálint Kuzsinszky for the palaestra (Cat. 14) (Kuzsinszky, 1891; Table 1).

entirely certain. There are several reasons for the uncertainty. One is that the amphitheatre is not mentioned on the board, and the other being that Antoninus Pius' name, which is incorrectly written on the caption, is in the dative. On this basis, attempts were made to link it to the construction of a triumphal arch (Fehér and Kovács, 2003:pp.192-193), but the arguments are not convincing. Based on the location of the inscription and international parallels (above the three entrances to Lambaesis's amphitheatre, there was a similar construction inscription, none of which mentions the amphitheatre), it is likely that the construction inscription of the amphitheatre has been found. This view is also expressed by Margit Németh (Németh, 1999:p.18-19).

Unfortunately, the constructional inscription of Aquincum's civil amphitheatre has not been found, but two of the stone monuments documenting its renovation have survived (Cat. 16, Cat. 17). One commemorates the successful completion of the amphitheatre gate renovation. Fragments of its table are $40 \mathrm{~cm}$ high and 6-32 cm wide and have traces of whitewash in its indentations. Column No. 22 was found nearby (Torma, 1881:p.78). There are seven names - two of them probably belong to the same family - on the board of directors adored for Iuppiter Optimus Maximus and probably Iuno. These are probably the names of the citizens of Aquincum who were financially supporting the renovation. There was no reference to the inscription on the venue board to assist in the inscription. Károly Torma, from a mere $7 \mathrm{~cm}$ fragment, also found next to column No. 22, suggests that it is likely to be related to the restoration of the gates (Torma, 1881:pp.79-80). Studies of a travertine slab with only two letters - AS - indicate that it may be a piece of the upper part of a memorial plaque and possibly the fragment of the [... port] as [reficiendas] inscription.

The other inscription on the renovation, which documents the restoration of the auditorium sections of the bourgeois amphitheatre, is similarly fragmentary (Cat. 17). The fragment, which is the lower-left corner of a stone slab, was probably found in "Papföld" before 1890 (Kuzsinszky, 1904:p.174). Bálint Kuzsinszky published a drawing of the inscription of the stone fragment in 1904 (Fig. 4) but considered that it is incomprehensible due to its truncated lines. The inscription was interpreted only

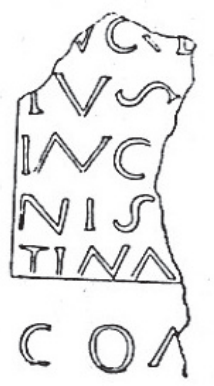

Fig. 4 Drawing of Bálint Kuzsinszky from 1904, a fragment of an inscription on the restoration of parts of the amphitheatre auditorium. (Cat. 17; Kuzsinszky, 1904:p.174). 
in 1971, although Szilágyi also noted that, since the text was very damaged, the resolution he proposed was uncertain. If the supplement was correct, a remarkable fact was recorded on the board, namely, that there was a sufficient budget for the restoration. Also, that amount, which was no less than fifty-five thousand sestertius, was spent on the renovation of the cortinae (vault) (Kuzsinszky, 1904; Szilágyi, 1971:p.309). There were also several ideas in the name of the collection supervisor during the addition. Attempts have been made to refer to the three solid letters, INC or ING, for persons whose names appear on other Aquincum stones, but the name of the latter is preceded by at least one letter, and INC is right next to the frame (Szilágyi, 1971:p.309). Therefore, the name of the supervisor could be Marcus Ingenus Maro.

The in situ inscribed stone monuments of the civil town amphitheatre are the remaining inscriptions on the seats (Cat. 18). The excavated, inscribed sediles were also very different in length, height and width. Károly Torma justified this due to the height differences that were compensated for by different levels of filling. For each of them, as Torma says, the name or initials of the citizen's names were engraved on the stone - in some cases, followed by a space after the letter $\mathrm{S}$, the abbreviation of the sedile where it was. For a single stone fragment, only the one where the $\mathrm{N} \mathrm{O}$ pair appears is uncertain. He speculates that this might be a piece of a podium ledge on which the cuneus (the arrow-headed area of the grandstand) number has been engraved, only pairs of letters have been used instead of numbers. According to that finding, N O would have designated the seventh cunei (Torma, 1881:p.49). However, this interpretation suggests that similarly to some other sediles, the initials of a praenomen and a cognomen can be on it. The cuneus designation also seems to be refuted by the fact that the cuneus designation stones found in Puteoli contain the word cuneus and the number beside it.

There is one among the several inscribed sedile that not everyone agrees with. Károly Torma copied from the stone the letters BOI VIL, which he identified as the seat of Boi(i) or Boi(oduri) vil(ici), that is to say, perhaps a public servant, servus vilicus (Torma, 1881:p.51). However, the letters on the still existing stone fragment can be read and interpreted differently. Next to the letters VI, only a partial letter follows the space, which may be E rather than L. In the case of the BOI VI E, which can be reconstructed in this way, according to the Lugdunum example, where members of different tribes were given a certain number of seats in the amphitheatre. It could also be said that the boii (members of the Celtic tribe Boius, i. m.) received six seats. Then there might have been another tribal name perhaps the eraviscus - and a place.

One of the inscribed seats is worth mentioning: it is the one that marked the bisellium. The $1.58 \mathrm{~m}$ long, $0.67 \mathrm{~m}$ high and $0.68 \mathrm{~m}$ deep sedile was used to calculate the number of the cavea seatings in the way, that a half of the bisellium, which was the place of Valerius Iulianus and Aelius Quintus, was a person's seat requirement (Torma, 1881:p.48).

The four stone fragments found near the Krempel Mill in 1875 cannot be classified as sedile (Fig. 5). Two of the four fragments, the one with Roman numerals and the one with worm-like armrests, belong together. From this, it became clear that these were two pieces of a sella - or rather a cathedra. The reconstructed fragments suggest that it could originally have served as a seat for eight people. Although a similar stone fragment was found in Pompeii, Soproni interpreted it as a local calendar, ignoring Károly Torma's interpretation. More sediles have been found over time, bringing the number of inscriptions to 27, and published in 1891 by Bálint Kuzsinszky (Kuzsinszky, 1891:pp.109-112). Interestingly, only two of them can be found today and, recently, a piece of the sella, with numbers of location, in the warehouse of the Hungarian National Museum.

\section{The case of basilica, collegium and triumphal arch}

We still have three inscriptions on the public buildings of the city, but we have no archaeological evidence of where they might have stood.

The first is the inscription on the construction of a basilica (Cat. 19). Unfortunately, the inscription is so fragmentary that the only record relates to the fact that the basilica was built - or possibly renovated. It is not possible to supplement it according to our present knowledge.

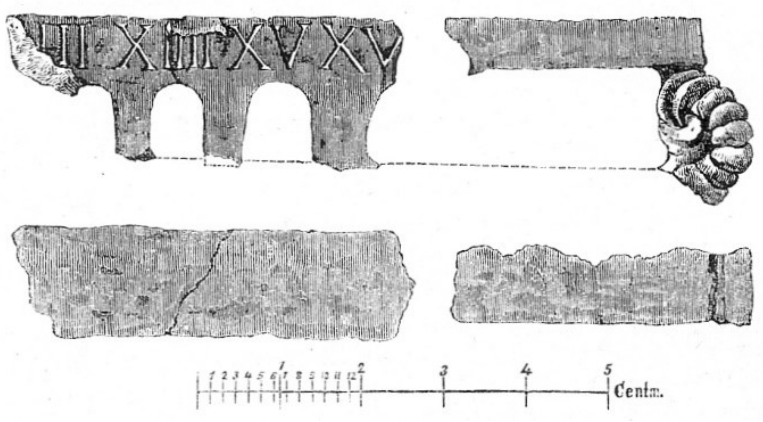

Fig. 5 Pieces of sella found in the civil town amphitheatre. (Cat. 18; Torma, 1881:p.50). 
The inscription on the construction of a college headquarters is also somewhat fragmented (Cat. 20). The stone inscription found by Bálint Kuzsinszky in a tabernacle to the southwest of the macellum (marketplace for meat) in 1931 lacks the part that contained the name of the collegium. This subtitle fragment is also problematic because Kuzsinszky only produced a datasheet about it and did not propose to resolve it. Later, the following note was added to the datasheet by Lajos Nagy: "collegiumi schola. . . suis refecit" (Szilágyi, 1973:p.152). Based on this, János Szilágyi proposed a supplement to the catalogue. Consequently, the inscription only says that the collegium was established from private money.

There are also two other building inscriptions associated with the collegium (Cat. 21, Cat. 22), which relate to the south-western region of the canabae.

One of them is a broken stone slab (Cat. 21), discovered during the founding of an apartment building in Pest in 1900, which is commemorated by the construction of a banquet house (Szilágyi, 1949:p.19) or kitchen (Kuzsinszky, 1904:p.167), and is currently bricked in the stone vault of the Aquincum Museum. The almost intact inscription is especially significant in social history because the three magistrates mentioned in the inscription are members of the superintendent of the collegium Victorianorum that erected the building. It must have been Aquincum's most populous collegium because it had at least six groups. One of them, Caius Iulius Pacatus was the head of construction and the priest of the fanum of the collegium. After the three magistrates, decuriones are represented in the text, except for Vibius Lucius, supervisors of the building. We also know the patron of the collegium, Cnaeus Marcus Masvetus. The date of the Consul reveals that the construction took place in $223 \mathrm{AD}$. Consequently, this building was constructed by Emperor Severus Alexander. Besides the real purpose of the building, where the name of the collegium is not clear. Bálint Kuzsinszky raised the possibility that he might be called Victorianorum (Kuzsinszky, 1904:p.167) because the emperor was always a victor, and János Szilágyi defined him as the believer of the goddess Victoria, the "organisation of the imperial invincibility" (Szilágyi, 1949:p.20).

The construction of a fountain made by a member of the collegium fabrum, a particularly significant public organisation, is traced to a stone plaque found in the ruins of the Trinitarians in 1778 (Cat. 22). The collegium fabrum worked in an association with the postmen until $150 \mathrm{AD}$, called collegium fabrum et centonariorum. (After their severance, the collegium fabrum in canabae and the collegium centonariorum in the civil town were the fire departments.) Like the previous one, it also provided social benefits. The fountain was claimed by Caius Iulius Severus because he became one of the magisters of the collegium fabrum. Such offerings and constructions of gratitude or votive acts were typical, customary, almost expected. The Aquincum organ was likely one such gift given to the association by the commander of the collegium fabrum for the post he received (Szilágyi, 1956:p.38; Zsidi, 1998:p.92).

There have been different opinions about where this fountain might have been. János Szilágyi puts the silanum in the civic town and suggests that it may be related to one of the two archaeological findings found in the civil town. One is a piece of a cylinder of a marble ornamental well, and the other is an imprint of the wall of a public well or a round water basin found next to a public bath built in the centre (Szilágyi, 1956:p.33). Klára Póczy has a completely different opinion. She ties this caption to the south-western region of the canabae and suggests that it was on a forum there (Póczy, 1983:pp.261-262).

The same localization problem occurred with another caption. An inscription found next to Vörösvári út in 1882 (Cat. 23) documents that Caius Titius Antonius donated some kind of decoration to the forum of the municipium. The name of Caius Titius Antonius had already been found on an earlier inscribed stone monument (Cat. 11). According to his testimony, he had a nymphaeum built in the civil town with his own money. As before, János Szilágyi places the ornament donation inscription on the forum of the civil town, while Klára Póczy places it on the main square of the southwestern region of the canabae.

Similarly, to the inscription on the building of the collegium headquarters (Cat. 20), Bálint Kuzsinszky found a marble plaque in several pieces, which was later displayed on the north-east wall of the U-shaped lapidary of the new building of the Aquincum Museum; this proves the rebuilding of the four commercial premises (Cat. 24). Kuzsinszky did not suggest a supplement to the text (Szilágyi, 1971:p.307), and later additions became difficult because of the inaccurate joining of pieces of the board and the deterioration of the stone. In 1971, when the inscription was first published, János Szilágyi prepared suggestions for them. From these, it emerges that a senior citizen of the municipium, Titus Flavius Fortio/Corvio - his third name is uncertain - was the one who rebuilt the four commercial places the second time [in solo [ref(ecit) I(terum)] (Szilágyi, 1971:p.308). Unfortunately, there is no data to assist with dating, so we do 
not know if the barbaric invasions necessitated reconstruction or was it simply a modernisation. The former seems more probable, and therefore the inscription, appearing in the $2^{\text {nd }}$ Century AD, can finally be dated.

The construction of the brick triumphal arch from the personal asset of Caius Iulius Sextimus is also related to the civil town (Cat. 25) (Szilágyi, 1956:pp.27, 29). The triumphal arch stood on the main street - which departed from the harbour - of the civil town, namely, it was founded in a public place-locus public-donated by the city council for this purpose. Caius Iulius Sextinus was a Syrian publican. (It should also be noted here that collegium surorum, or Syrian collegium, was a state licensed organisation.) That is why the plaque commemorating his deed is decorated with the reliefs of Dea Syria and Iuppiter (Póczy, 2004:p.254). The right side of the board is completely broken, but the rest of the board can be reconstructed. A fragment of the upper-right text box reveals that the missing relief could have depicted Dea Baltis (Kuzsinszky, 1937:p.136).

\section{Inscriptions on milestones}

The milestones represent a completely different group, which, in addition to their distance from the settlement, also reported on various construction and renovations. Two such multifunctional milestones were found in Aquincum (Cat. 26, Cat. 27). The first (Cat. 26) was erected eight miles from the border of Aquincum. (A Roman mile is 1480 metres long. Roman miles $=1000$ double steps or 5000 feet. 1 step $=74 \mathrm{~cm}$.) On the cylindrical mile, the inscriptional field is shaped like a panel (Fig. 6). The framed field captures the fact that Severus Alexander has renovated the road.

The major Pannonian carriageways, including this one, were made with great technical care. A multi-layer foundation was laid with a rammed earth layer and then covered with basalt slabs (Póczy, 2004:p.50). The subtitle box clearly shows that the second and fourth lines have been deleted. This is because the name of the emperor, who was later sentenced to be a damnatio memoriae, stood here. The distance from Aquincum - AB Q M P / VIII - is engraved on the limestone roller below the table. The letters were painted red, the traces of which are still visible today (Nagy, 2007:pp.144, 149).

The second, two milestones from Aquincum (Cat. 27), reports that Macrinus had reconstructed the roads and bridges between 217 and 218 AD. The renovation was, of course, not supervised by the emperor, but by its

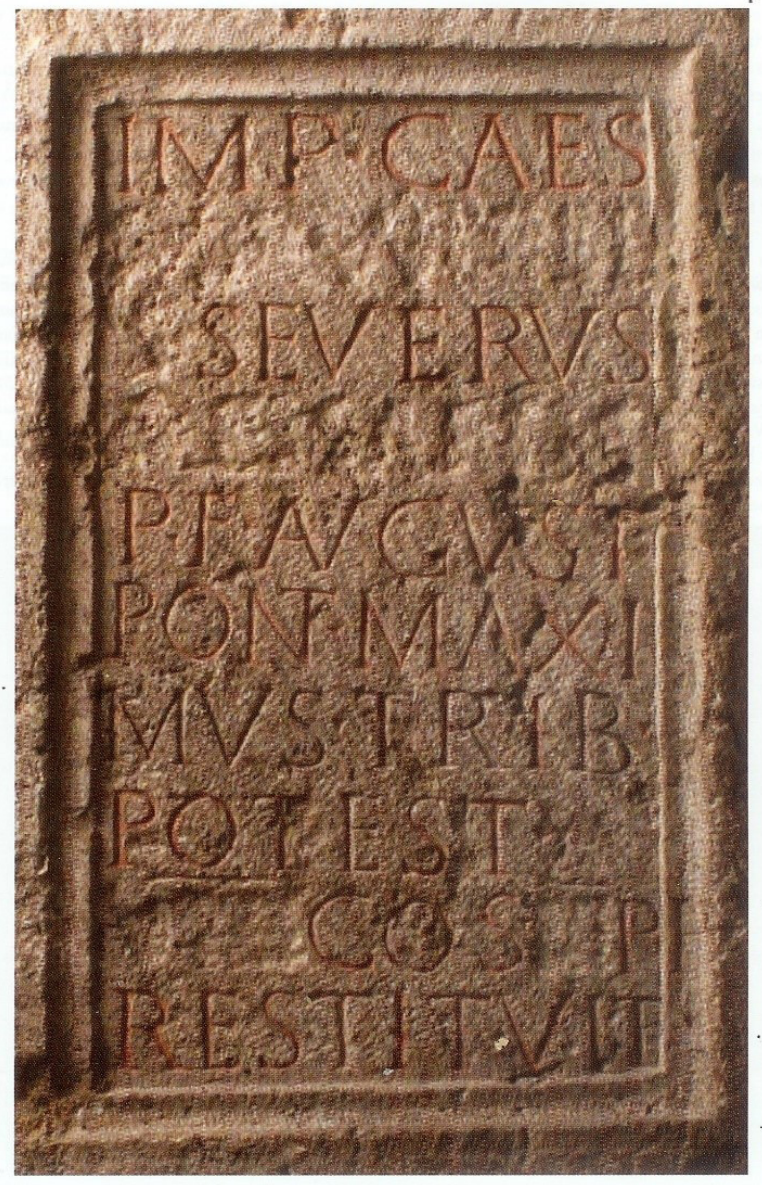

Fig. 6 An inscription on a landmark set eight miles from Aquincum. (Cat. 26; Nagy, 2007:p.154.)

legate, Aelius Triccianus, and it was he who was responsible for the maintenance of the city's road network (Kuzsinszky, 1900:p.8).

Apart from these two milestones, several further examples are known. It is of unique interest, that among these, there are three others, which were also two miles from the city (Cat. 28, Cat. 29, Cat. 30). More interestingly, two of them (Cat. 28, Cat. 29) were claimed by the same emperor, Caius Iulius Verus Maximinus. The only difference is that in the second case, besides Maximinus, the name of his son, Caius Iulius Verus Maximus, is also mentioned. On three other Pannonian milestones - the examples of Fadd (CIL III 10645), Podgajce (CIL III 6465) and Pilisszántó (CIL III 11340) - only the name of Maximinus is engraved (Kuzsinszky, 1900:p.10). The third milestone was made during the reign of Philippus Arabs. The following is an effective approach for analysing the "template" of milestone inscriptions according to which almost every milestone is written. First was the name of the emperor, with his full title, and possibly even his child, who may have 
been co-ruler, or his wife. (Since Iulia Domna, the Augusta had the right for the title of mater castrorum.) Then followed the builder - if it was not the emperor - and finally the city and its distance from Rome in double steps. If the landmark was ordered by the emperor, or was rebuilt by the emperor, the bridge where the stone stands was replaced by the construction supervisor instead of the builder.

\section{Conclusion}

There are several facts that can be deduced from the inscribed stone monuments documenting the construction and renovation of Aquincum's public buildings and structures. Looking at the location of the stone slabs and fragments (Fig. 7), it is clear that most of them were found in the area of the military city and its surroundings. The map also shows that the excavation work on road constructions of the $20^{\text {th }}$ century contributed to the appearance of most of the monuments, since the sites are in most cases along or in the immediate surroundings of the roads.

Looking at the text of the inscriptions (Table 1), it appears that the constructions were mainly in the Severus era, when Pannonia and especially Aquincum were in their golden age. The large number of inscriptions on the renovation suggests that the Marcomanni Wars and other barbaric invasions in the area of Aquincum were devastating, and that reconstruction works had been going on for decades.

An analysis of the names and positions of the builders and donors gives an insight into the life of the city. There is, for example, the composition of a collegium (Cat. 21), or the custom that, when a person has received an important position, he usually enriched his city with some building (Cat. 10). It also becomes evident that the

\section{References}

Alföldi, A. (1940) "Epigraphica III." (Epigraphica III.), Archaeologiai Értesítő, 3(1), pp. 195-213. (in Hungarian)

Alföldi, A. (1943) "Aquincumi adalék a Kr. u. 268. év történetéhez" (Data from Aquincum to the history of the year 268 AD)), Budapest Régiségei, 13, pp. 33-43. (in Hungarian)

Bánosi, Gy. (1984) "Újabb adalékok az aquincumi Hercules-kultuszhoz" (New data to the cult of Hercules in Aquincum), Budapest Régiségei, 24, pp. 43-51. (in Hungarian)

Borhy, L. (2009) "Brigetiói amphitheatrumok?" (Amphitheatres in Brigetio?), Pytheas Kiadó, Budapest, Hungary. (in Hungarian)

B. Thomas, E. (1955) "Az aquincumi palaestrák" (The palaestras in Aquincum) Budapest Régiségei, 16, pp. 89-103. (in Hungarian)

Fehér, B., Kovács, P. (2003) "Pannonia története Kr.u. 54-166 közt" (History of Pannonia between 54-166 AD), In: Az ókori Pannonia történetének forrásai, Károli Egyetemi Kiadó, Budapest, Hungary. (in Hungarian)

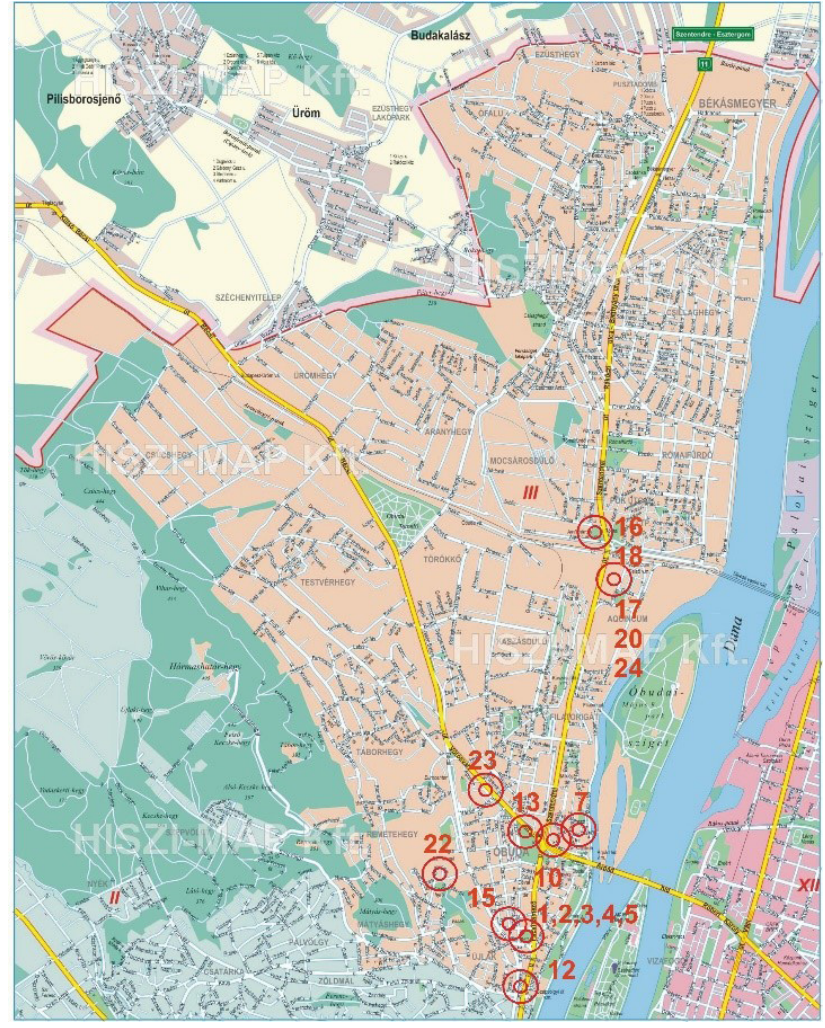

Fig. 7 The location of the inscribed stone monuments in the catalogue on the present map of Óbuda.

construction of the city centre was almost always constructed from the personal budget of wealthy citizens. The imperial investments created the road network and the larger buildings of the canabae.

\section{Abbreviations \\ AnÉp: L'Année Épigraphique \\ CIL: $\quad$ Corpus Inscriptionum Latinarum \\ EDH: $\quad$ Epigraphic Database Heidelberg}

Fitz, J. (1993-1995) "Die Verwaltung Pannoniens in der Römerzeit I-IV" (Die Verwaltung Pannoniens in der Römerzeit I-IV)), Enciklopédia Kiadó, Budapest, Hungary. (in German)

Fröhlich, R. (1891) "Aquincumnak római feliratai" (Roman inscriptions of Aquincum), Budapest Régiségei, 3, pp. 143-164. (in Hungarian)

Gabler, D. (1967) "Újabb feliratos kőemlék az ácsi táborból" (New inscribed monument from the Roman camp in Ács), Archaeológiai Értesítő, 94(1), pp. 194-197. (in Hungarian)

Heidelberg Academy of Sciences and Humanities "Epigraphic Database Heidelberg", [online] Available at: https://edh-www.adw.uniheidelberg.de/home?\&lang=en [Accessed: 05 May 2020]

Kaba, M. (1984) "Újabb kutatások az aquincumi Thermae Maiores területén 1979-ben és 1981-ben (előzetes jelentés)" (Latest research int the field of "Thermae maiores" in Aquincum in year 1979 and 1981) (Preliminary report), Budapest Régiségei, 25, pp. 181-225. (in Hungarian) 
Kuzsinszky, B. (1889) "A legújabb aquincumi ásatások, 1887-1888" (The latest excavations in Aquincum, 1887-1888), Budapest Régiségei, 1, pp. 38-170. (in Hungarian)

Kuzsinszky, B. (1891) "Az aquincumi amphiteatrum: Az 1890. és részben 1891-ki papföldi ásatások" (The amphiteatrum in Aquincum: The excavations at Papföld in 1890 and partly in 1891), Budapest Régiségei, 3, pp. 83-139. (in Hungarian)

Kuzsinszky, B. (1900) "Római feliratok az Aquincumi Muzeumban" (Roman isnscriptions in the museum of Aquincum), Budapest Régiségei, 7, pp. 3-66. (in Hungarian)

Kuzsinszky, B. (1904) "Római feliratok az Aquincumi Muzeumban" (Roman isnscriptions in the Aquincum Museum), Budapest Régiségei, 8, pp. 159-176. (in Hungarian)

Kuzsinszky, B. (1934) "Aquincum: Ausgrabungen und Funde" (Aquincum: excavations and findings), Franklin, Budapest, Hungary. (in German)

Kuzsinszky, B. (1937) "Az aquincumi múzeum római kőemlékeinek ötödik sorozata" (The fifth series of Roman stone monuments of the Aquincum Museum), Budapest Régiségei, 12, pp. 63-152. (in Hungarian)

L'Année Épigraphique (AnÉp) (1976) "Pannonie" (Pannonia), L'Année Épigraphique, 1980, pp. 151-157, inscription number: 541. [online] Available at: https://www.jstor.org/stable/25607109 [Accessed: 05 May 2020] (in French)

L'Année Épigraphique (AnÉp) (1979) "Pannonie" (Pannonia), L'Année Épigraphique, 1982, pp. 138-144, inscription number: 469. [online] Available at: https://www.jstor.org/stable/25607254 [Accessed: 05 May 2020] (in French)

L'Année Épigraphique (AnÉp) (1990) "Pannonie" (Pannonia), L'Année Épigraphique, 1993, pp. 229-239, inscription number: 805. [online] Available at: http://www.jstor.org/stable/25607649 [Accessed: 05 May 2020] (in French)

Nagy, M. (2007) "A Magyar Nemzeti Múzeum régészeti kiállításának vezetöje: Római kőtár" (Guide to the Archaeological Exhibitions in the Hungarian National Museum: Roman Stones), Magyar Nemzeti Múzeum, Budapest, Hungary. (in Hungarian)

Nagy, T. (1976) "Salariarius legionis - salariarius coloniae" (Salariarius legionis - salariarius coloniae), Acta Archaeologica Academiae Scientiarum Hungaricae, 28, pp. 79-91. (in Hungarian)

\section{Catalogue}

Cat. 1:

Location: Found alongside the southern wall of the Nemesis sanctuary.

$\mathrm{Fa}[$ num $\mathrm{Ne}$ ] mes[is . . C]hrysantus [et Ae]mil(ius) Fu[na]ti[anus?] a so[lo fac(iendum) cur]a[verunt ....... . et [ . . . . co(n)s(ulibus)]

The sacred site / temple of Nemesis... .Chrysantus and Aemilius Funatianus have been completely / completely provided from the basis.... and.... consuls year (Kuzsinszky, 1891:p.119).

\section{Cat. 2:}

Location: Found alongside the southern wall of the Nemesis sanctuary. [ . . . . fanum? Deae Ne]me[sis reginae] inst(ituit) a [solo ... .]

... sanctuary has been erected for Goddess Nemesis and Queen by.... $20.5 \mathrm{~cm}$ below, $16.5 \mathrm{~cm}$ above (Kuzsinszky, 1891:p.119).
Németh, M. (1999) "Vezető az Aquincumi Múzeum kőtárában" (Guide for the Lapidarium of the Aquincum Museum), Budapest History Museum, Budapest, Hungary. (in Hungarian)

Póczy, K. (1983) "Az aquincumi katonaváros utcahálózata és fontosabb épületei a II. és a III. században", (The street network and important buildings of the Military City of Aquincum in the II. and III. centuries), Archaeológiai Értesítő, 110(1), pp. 252-273. (in Hungarian)

Póczy, K. (2004) "Aquincum, Budapest római kori történelmi városmagja" (Aguincum, The historical city centre of Budapest in the Roman Age), Enciklopédia Kiadó, Budapest, Hungary. (in Hungarian)

Rómer, F. (1878) "Kiadatlan római feliratok. XIV-dik közlés" (Unpublished Roman Scripts. Publication no. XIV), Archaeologiai Közlemények, 11(1), pp. 27-46. (in Hungarian)

Szilágyi, J. (1949) "Beszéljenek a kőemlékek - vezető az Aquincumi Múzeum írásos kőemlékei között" (Let the stone monuments speak - Guide for the inscripted stone monuments of the Aquincum Museum), Budapest Főváros Kiadása, Budapest, Hungary. (in Hungarian)

Szilágyi, J. (1956) "Aquincum" (Aquincum), Akadémiai Kiadó, Budapest, Hungary. (in Hungarian)

Szilágyi, J. (1971) "Vitás és közöletlen rómaikori kőfeliratok az Aquincumi Múzeumból" (Debated and unpublished stone scripts of the Roman Age from the Aquincum Museum), Budapest Régiségei, 22, pp. 301-329. (in Hungarian)

Szilágyi, J. (1973) "Közöletlen feliratok Aquincumból" (Unpublished inscriptions from Aquincum), Budapest Régiségei, 23, pp. 147-158.

Torma, K. (1881) "Az aquincumi amphitheatrum északi fele. (Jelentés az ottani ásatásokból)" (The Northern Part of the Amphitheatre in Aquincum (Report from the excavations there)), Magyar Tudományos Akadémia Könyvkiadó, Budapest, Hungary. (in Hungarian)

Zsidi, P. (1998) "Az aquincumi tűzoltók kollégiuma és a tűzoltószékház" (The College of the Firemen in Aquincum and the FireOfficers Headquarters), Budapest Régiségei, 32, pp. 91-97. (in Hungarian)

Cat. 3:

Location: Found in situ in front of the back walls of the cell of Nemesis temple. Votive altar stone.

Nemesi / omnipoten / ti Aug(ustae) / M(arcus) Ulpius /5 Zosimus / XII k(alendas) sept(embres) Rus / tico II et Aquilin(o) (consulibus) In the year of the majestic, almighty Nemesis, Marcus Ulpius Zosimus, Rusticus second and Aquilinus consul.

Date: Aug. 21, 162. AD

Height: 120, width: 43

CIL III 10441 (Kuzsinszky, 1891:p.117).

Cat. 4:

Location: Aquincum - Budapest III. dist. / Óbuda, Szentendrei Street, Csiga Hill. Next to the civic amphitheater in 1876. 
Pro salute d(omini) n(ostri) / Imp(eratoris) M(arci) Aurel(i) An/t onini Aug(usti) / Aureli Florus et M /5 ercator IIvir(i) q(uin)q(uennales) / c[o]l(oniae) Aq(uinci) templum / [Ne]mesis vetustate / [con]lapsum restituer(unt) / [Messalla] et Sabi(no) co(n)s(ulibus) VIII K(alendas) Iul(ias) /10 [d(edit) d(edicavit) A]ur(elio) Suro sala(riario)

To the Salvation of Our Lord Imperator Marcus Aurelius Antoninus Augustis Aurelius; the urban principals with the duty of the five year wealth estimate of the colony of Aquincum, Florus and Mercator have restored the Temple of Nemesis on the eight day before Calendae of July which had been collapsed because of its old status. Saluted by Aurelius Surus, who had been honoured for his work / or: who is originated from the city of Sala/. Saluted the temple of Silus Messala and (Suetrius) Sabinus nalcaya in July, the year of the collapse of the temple of Siles Messala and (Suetrius) Sabinus. Offered by Aurelius Surus, who has been honored for his work / or: from the city of Sala /.

Date: Jun. 24, 214 AD

CIL III 10439 (Rómer, 1878:pp.29-30; Nagy, 1976:pp.79-91; Fröhlich, 1891:pp.155-156; AnÉp, 1976:p.153, inscription number:541; Póczy, 2004:p.111).

Cat. 5:

Location: Óbuda, Csiga Hill, from the foyer of the Nemesis Sanctuary of the bourgeois amphitheater. Originally it was in the sanctuary wall.

Deae Dianae Nemesi Aug(ustae) / honoribus et fa(v)oribus / G(aio) Iul(io) Victorini (!) eq(uo) p(ublico) aedili(cio?) / IIvirali et T(ito) Fl(avio) Luciano /5 q(uaestoricio?) IIvirali pontificibus / q(uin) q(uennalibus) col(oniae) Aq(uincensium) / Pupili(us) Hyliatianus / antesstis (!) numini eius /10 deae posuit V kal(endas) Iulias

Vertically on the left side of the frame: Aemiliano

Vertically on the right side of the frame: et Bas(s)o co(n)s(ulibus)

To the majestic goddess Diana Nemesis! Erected with devoted respect five days before the Calenda of June under the Consulate of Aemilianus and Bassus by Knight Gaius Iulius Victorinus, with the position of Aedilis and Duumvir, and Titus Flavius Lucianus, Quaestor and Duumvir, of the fifth year (in office) priests of Aquincum colonia, Pupilius Hyliatianus, dean of the goddess.

Height: 58.5, width: 58.5, thickness: 11;

Date: June 27, 259. AD

CIL III 10440 (Torma, 1881:p.72; Kuzsinszky, 1891:pp.117-118; Nagy, 2007:p.154; Póczy, 2004:p.111).

Cat. 6:

Balti diae / divinae et / Diasuriae / templum f(ecit) / T(itus) Fl(avius) Titus Flavius has constructed a temple to Goddess Baltis and Dea Syria. Date: cc. $3^{\text {rd }}$ century CIL III 10393 (Kuzsinszky, 1937:p.141).

Cat. 7 (a):

Location: District III, Harrer Pál Street

$\mathrm{He}[$ rculi sac(rum)] / pro salu[te et incolumitate domini nostri] / imp(eratoris) caes(aris) [M(arci) Aur(elii) Severi Antonini Pii Felicis] / Invicti A[ug(usti) Parthici max(imi) Britannici max(imi)] /5 Germanici M[ax(imi) et Iuliae Domnae Augustae] / matris August[i coh(ors). . .] / templum Herculis [vetust(ate) conlapsum restituit] / a fundamentis adie[cto portico sub c(ura) . . . ] / Cattio Sabino II [et Cornelio Anullino co(n)s(ulibus)] (Bánosi, 1984:p.50).

Cat. 7 (b):

$\mathrm{He}[$ rculi Aug(usto) sac(rum)] / pro salu[te et incolumitate domini nostri] / Imp(eratoris) Caes(aris) [M(arci) Aur(eli) Severi Antonini Pii Felicis] / Invicti Au[g(usti) Parthici max(imi) Britannici $\max (\mathrm{imi})] / 5$ Germanici m[ax(imi) et Iuliae Domnae Augustae] / matris August[i et castrorum 3] / templum Herculis [3] / a fundamentis adie[cta(?) porticu(?) ex voto fecit] / Cattio Sabino II [et Cornelio Anullino co(n)s(ulibus)]

The Blessed Temple of Hercules has been constructed for the salvation and integrity of Our pious, felicitious and invincible Lord the Emperor Caesar Marcus Aurelius Severus Antoninus, the mighty conqueror of the Parthians, the British, the Germans, and the blessed Lady, Iulia the mother of Augustus and the Camps, with a porticus / colonnade joining, made from the ground up as a votive / gift during the second consulate of Cattius Sabinus and the first consulate of Cornelius Anullinus.

Date: 216. AD

(AnÉp, 1990:p.233, inscription number:805).

Cat. 8:

[Imperat]ores d[d(omini) nn(ostri) L(ucius) Sept(imius) / S] everus et M(arcus) [Aur(elius) Antoninus / Aug] usti templu(m) D[olicheni ve / tus] tate conlap[sum restitu / erun]t cur[ante . . .

Our two masters, Imperator Lucius Septimius Severus Augustus and Imperator Marcus Aurelius Antoninus Augustus, have been rebuilt the temple of Dolichenus which was collapsed because of old age, under the supervision of ...

Date: 202. AD

(Alföldi, 1940:pp.197-198; Szilágyi, 1956:p.14).

Cat. 9:

Genio v[aletudin(arii?) leg(ionis)] / II Adi(utricis) P(iae) F(idelis) Se[ver(ianae) templum] / a solo sum[ptibus suis] / cum cubicu[lo et porticu(?)] $/ 5$ fecit $\mathrm{Au}[\mathrm{r}$ (elius?) ... ex] / cand(idato) [factus centurio ex] / suff[rag(io) ... Eg]/na[ti

The temple of the genius of the Hospital of the pious, very loyal legio II. Adiutrix was built from its bases with dormitories / infirmaries and a portico at his own expense.

Date: between 222-235. AD

CIL III 10403 (AnÉp, 1979:p.141, inscription number:469).

Cat. 10:

Location: Óbuda, Tobacco factory.

C(aius) Cornel(ius) Corinthus / ob Augustalitatem / splendidissimo templum / II PEP

According to Róbert Fröhlich:

C(aius)Cornel(ius) Corinthus/ob Augustalitatem/splendidissim[am?] templum / iterum [r]e[f(ecit)?]

According to János Szilágyi:

C(aius) Cornel(ius) Corinthus / ob Augustalitatem / splendidissimo templum / II rep(aravit) 
Caius Cornelius Corinthus renovated the temple for the second time because of winning the position of Augustus

CIL III 3579 (Fröhlich, 1891:pp.162-163; Szilágyi, 1956:p.34).

Cat. 11:

Location: Báthmonostor: reused on the wall of the temple.

[C(aius) Tit(ius) Anto]n[ius] / [Peculia]ri[s dec(urio)] / [col(oniae) [Aq(uincensium)] eq(uo)] p(ublico) de[c(urio)] m(unicipi) [S[in] g(iduni)] / [IIvir f]la[m(en) sacerdos] /5 arae Aug(usti) n(ostri) [p(rovinciae) P(annoniae) Infer(ioris) nymf(eum)] / [pec(unia) s] $\mathrm{u}[\mathrm{a} \mathrm{f}] \mathrm{eci}[\mathrm{t}]$ et / [aqua]m induxit

Caius Titius Antonius Pecularis, the decurion of Colonia Aquincum, and the decurion of Singidunum municipium which is on the same land, the of IIvir flamen sacerdos of our Emperor cult altar established the Nymphaeum of Pannonia Inferior of his own cost and conducted water to it.

Date: cc 200 AD

CIL III 10496 (Heidelberg Academy of Sciences and Humanities, EDH, HD number: HD038224).

Cat. 12:

Location: Aquincum - Budapest, District III. / Óbuda, 5. Kolosy Square

Imp(erator) Caesar / M(arcus) Aur(elius) Severus / [[Alexander P(ius) F(elix) Aug(ustus)]] / balneum a solo /5 territorio leg(ionis) / II Ad(iutricis) P(iae) F(idelis) S(everianae) fecit / curante Fl(avio) / Marciano co(n)s(ule)

The end of the text according to Margit Németh: CO(N)S(ULARI)

Emperor Marcus Aurelius Severus (Severus Alexander) built a bath on the territory of the Legio II Adiutrix pia fidelis Severiana under the direction of Governor Flavius Marcianus.

Date: Between 222-235 AD

CIL III 10489 (Kuzsinszky, 1904:pp.164-165; Fitz, 1993-1995:p.1041, inscription number:681; Németh, 1999:p.64).

Cat. 13:

Location: Aquincum - Budapest, District III. / Óbuda, 420. Flórián Street

Thermas maiores / leg(ionis) II Adi(utricis) Claudianae / magno tempore in/[te]rmissas et destitutas $/ 5 \mathrm{r}[\mathrm{e}]$ tractatis porticibus / aditibusque [pri]us refeci[t] / exhiberi inde [inc]episse / militib(us) [iuss]it [pri]die Kal(endas) Iuli(as) / praes[ide pr(ovinciae) e(gregio)] v(iro) Clemen(tio) Silvi(no) /10 et cura Aur(eli) Frontini pra/ef(ecti) leg(ionis) eiusdem Pater/no II et Mariniano co(n)s(ulibus)

The legio II Adiutrix Pia Fidelis Claudiana's larger baths, which had been unused and abandoned for a long time, were first rebuilt by repairs to columns and entrances, and ordered to be made available to soldiers on the day before the Calenda of July, during the Lieutenancy of the extraordinary man Clementius Silvius, under the supervision of Aurelius Frontinus, the commander of the same legion, during the Second Consul of Paternus and Marinianus.

Date: Jun. 30, 268. SD

CIL III 3525 = 10492 (Alföldi, 1943:pp.35-42).
Cat. 14:

The fragments of the two lines dipinti text:

Fragment 1. AN $\mathrm{AI} \rightarrow(\mathrm{M}) \alpha \dot{v} \lambda \mathrm{\lambda}(\mathrm{o} \varsigma)$

Fragment 2. NOY $\rightarrow$ the last syllable of the father's name

Fragment 3. AI $\Lambda \mathrm{IOC} \rightarrow$ in Latin: Aelius

Fragment 4. IA $\Lambda$ AIC $\rightarrow \pi \alpha \dot{\alpha} \alpha \iota \sigma \tau \rho \alpha$ $\Pi \mathrm{O} \Lambda \rightarrow(\ldots ..) \eta \vee \mathrm{vo}(\mathrm{v})$

Fragment 5. IAI

$\mathrm{O}$

Fragment 6. NIOCП

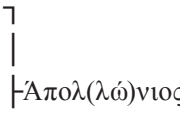

Fragment $7 . \quad \mathrm{HNO} \rightarrow$ it can refer to the origin

Fragment 8. $\quad$ PICTE $\Phi \rightarrow(\pi \varepsilon) \rho ı \tau \varepsilon \varphi(\alpha$ vov́ $\mu \varepsilon v o \imath)$

Fragment 9., 10., 11. still question

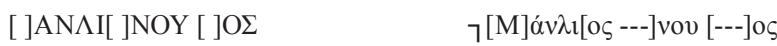
AI $\Lambda \mathrm{IO} \Sigma[] \mathrm{H}$ NO[ ] $\quad \mid A i ́ \lambda \operatorname{los}[---] \eta$ vo[---]

[ ]ПА $\Lambda$ AI $\Sigma[$ ]PATI[ ] $\quad \mid[---] \pi \alpha \lambda \alpha 1 \sigma[\tau] \rho \alpha \tau 1[\omega ́ \tau \eta \varsigma---]$

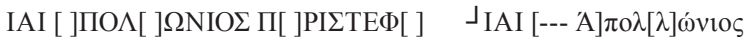
$\pi[\varepsilon] \rho 1 \sigma \tau \varepsilon \varphi[\alpha v 0 \mu \varepsilon ́ v o r---]$

(Heidelberg Academy of Sciences and Humanities, EDH, HD number: HD035870; Kuzsinszky, 1889:pp.120-124; B. Thomas, 1955:pp.89-103).

Cat. 15:

Location: Óbuda, 8. Viador Street. In front of the northern entrance of the amphitheatre. $\rightarrow$ It could be above the entrance.

Imp(eratori) Caesari / Tit(o) Aelio / Hadriano / Anto(n)ino /5 Aug(gusto) Pio p(atri) p(atriae) / co(n)s(uli) IIII leg(io) II Adi(utrix) p(ia) f(idelis)

To Titus Aelius Hadrianus Antoninus Pius Augustus, the father of the homeland, consults quarterly. The duty-bound, loyal legio II Adiutrix.

Date: Kr.u. 145.

(Kuzsinszky, 1934:p.180; Alföldi, 1940:p.203; Németh, 1999:p.18, Borhy, 2009:p.95).

Cat. 16:

Location: Support column 22; from the southern wall of the Nemesis Sanctuary.

$\mathrm{I}($ ovi) $\mathrm{O}$ (ptimo) $[\mathrm{M}($ aximo) / et Iun]o[ni reginae . . . . ] / [ . . ] Cas[ius $] /$ [. . . ] Val(erius) $/ 5$ [. . .] Arveso / C. Caviniu[s] / [ . . ] Val(erius) / L. Cassius / [p]ortas /[amphiteatri? .... .]

To the best, most powerful Iuppiter and Queen Iuno.... .... Casius... .Valerius... Arveso C. Cavinius... Valerius L. Cassius at the gates of the amphiteatrum.... (Torma, 1881; Kuzsinszky, 1891:pp.119-120).

Cat. 17:

Location: probably the 'Papföld' (before 1890)

... [nummos] LV (milia) [s(ub) c(ura) M(arci)] Ing(enui) [Maro]nis [ad cor] tina[s ref(iciendas)] con[tul(erunt)]

Problem: The lower left quarter of the building board remains. The completion is uncertain.

... 55,000 Sestertiuses were collected under the supervision of Marcus Ingenus Maronis to rebuild the auditorium of the amphiteatrum. (Kuzsinszky, 1904:p.174; Szilágyi, 1971:p.309). 
Cat. 18:

Inscriptions on the seats of the civil town amphiteatrum.

$\mathrm{NO}$

The first letters of Praenomen and cognomen or the $7^{\text {th }}$ letter pair which signs the number of $7^{\text {th }}$ Cuneus.

I L

The first letters of Praenomen and cognomen.

BOI VIL

Boi(i) or Boi(oduri) vil(ici), presumably the place of a tollman officer (servus vilicus).

VAL IULIANI ET AEL QUINTI
CLA FAB
G VALERIA NONIA
SEP
CLIT
IUL LICI S

Val(erii) Iuliani et Ael(ii) Quinti Cla(udius) Fab(ianus)

G(aia) Valeria Nonia

Sep(timii)

Cliti?

Iul(i) Lici vagy Lici(niani) s(edile)

BOANT S

LOCUS VAL

SEVERINI

AUR GENTILIS

FLO

$\mathrm{V}$ TE

[X]III XIIII XV XV[I]

Boant(i) s(edile)

Locus Val(erii)

Severini

Aur(elii) Gentilis

Flo(rus)

V(alerius) $\mathrm{Te}(. . . .$.

The numbers of wseats on the arms of sellas. (Torma, 1881:pp.47-53; Kuzsinszky, 1891:pp.109-112).

Cat. 19:

[Aur]eliu[s ---] / [---] Aug(ustus) Piu[s ---] / [--- b]assilicam(!) [---]/ [---]onin[---] / [---]a // [[---[a et Procl] --- ]] / [[------]] / [[--- [IXV] ---]] / [[--- [R] --- $]]$ / [[-------]]

(Heidelberg Academy of Sciences and Humanities, EDH, HD number: HD032901).

Cat. 20:

Location: Bálint Kuzsinszky was found in a tabernacle to the southwest of the Papellian macellum at the intersection in 1931.

... [sch]olam c[oll(egii ....)] [impendi(i)s s] uis [refecit ... .]

... rebuilt the association's headquarters at its own expense.

(Szilágyi, 1973:pp.152-153).

Cat. 21:

Location: Pest, excavating the foundations of a tenement house in 1900. Pro (sal)ute d(omini) n(ostri) Aug(usti) colleg(ium) / Victorianorum cocinator(ium) / collat(ionibus) suis [a]c instante / C. Iul(io) Pacato [m(agistro)] F(ani) colleg(ii) s(upra) s(cripti) / curatoribus L . . . ? Domit(io) Dom / itiano dec(urione) dec(uriae) quartae) m(agistro) F(ani) (quartum) et Ti(berio) / Asinni(o) Felicianus (sic!) dec(urione) d(ecuriae) (quintae) et / T. Sept(imio) Ingenus (sic!) dec(urione) d(ecuriae) (sextae)

Maximo ite[r](um) et Aeliano co(n)s(ultibus)

Cn. M. Masvetus pat(ronus)
Vib(ius) Lucius d(ecurio)

The kitchen built to the salvation of Our Lord, Augustus, was gathered by the victorianorum ("triumphant") association, and the zealously active C. Iulius Pacatus is the Temple's superintendent and curators, L... Domitius Domitianus, the fourth decuria decurio, quadruple caretaker, and Tiberius Asinnius Felicianus, the fifth decuria decurio, and T. Septimius Ingenus, the sixth decuria decurio.

In the year of the second consulate of Maximus and the first consulate of Aelianus.

Cn. M. Masvetus patronus

Vibius Lucius decurio

cocinatorium $=$ coquinatorium

Date: 223. AD

(Kuzsinszky, 1904:p.166).

Cat. 22:

Location: Found in Óbuda among the ruins of the Trinitarians in 1778.

C(aius) Iulius Severus ob ho / norem magisteri / coll(egii) f[a]brum silanum / pecunia sua fecit /5 Muciano et Fadiano co(n)s(ulibus)

Caius Iulius Severus made the fountain of his own expense on the occasion of his election to the leadership of the Craftsmen's Association, in the year of the consul of Mucianus and Fadianus.

Limestone, height: 72,5; length: 198; thickness: 23;

Date: 201. AD

CIL III 3580 (Nagy, 2007:pp.119-120; Fröhlich, 1891:162; Póczy, 1983:pp.259-260).

Cat. 23:

Location: Óbuda, nearby the road to Vörösvár, 1882.

C(aius) Tit(ius) C(ai) fil(ius) Serg(ia) (tribu) Antonius / P[e]cularis dec(urio) col(oniae) / Sept(imiae) Aq(uincensis) item dec(urio) $\mathrm{m}$ (unicipii) / S[i]ng(iduensis) ornamentum /5 forus reipublicae / d(ono) d(edit)

Caius Titius Antonius Pecularis, son of Caius from the Tribe of Sergia, the decurio of colonia Septimia Aquincum and similarly municipium Singidunum, donated decoration to the community's forum.

Date: $2^{\text {nd }}$ Century, AD - beginning of 3rd Century

Height: 180, width: 80, thickness: 15

(Fröhlich, 1891:pp.160-161; Póczy, 1983:pp.259-260).

Cat. 24:

Location: Papföld.

Recommendation for supplements:

T(itus) F[1(avius) F]or[ti]o v(index ? vates ?) [m(unicipii) A]q(uinci) $\mathrm{s}$ [ac(erdos] q[u(a)est(orius)] cu[r(ator)]

1(ocorum) v(enalium) r(emansorum) [taber]nas I[III] a solo [ref(ecit) I terum]

or

T(itus) F[1(avius) C]or[vi]o v(index ? vates ?) [m(unicipii) A]q(uinci) $\mathrm{s}[\operatorname{ac}($ erdos] $\mathrm{q}[\mathrm{u}(\mathrm{a}) \mathrm{est}$ (orius)] $\mathrm{cu}[\mathrm{r}$ (ator)]

1(ocorum) v(enalium) r(emansorum) [taber]nas I[III] a solo [ref(ecit) I[terum]

Titus Flavius Fortio / Corvio, the vindex, vates, sacerdos of municipium Aquincum, inspector in quaestor rank rebuilt from the ground in ruins remained 4 shop places of the commercial area. 
Date: end of the $2^{\text {nd }}$ century

(Szilágyi, 1971:pp.307-308).

Cat. 25:

Deae Syri[ae] / et [Balti de]/ae pro sa/lu[te Aug(usti)] /5 C(aius) Iul(ius) Sextinus con/ductor ex decr(eto) ordin(is) / $k$ (anabarum!) secund(um) conduct(ionem) arcum / cum ianuis tegu[1]a tectum / inpendi(i)s suis fecit mag(istris) / Iul(io) Viatore et Belli[c]io Firmino /10 1(ocus) p(ublice) d(atus) d(ecreto) d(ecurionum)

In honor of Dea Syria and the goddess Baltis, for the salvation of the Augustus, the tenant Caius Iulius Sextinus made a tile-covered arch with gates at his own expense, by the declaration of the canabe order according to contract, with magistrates Iulius Viator and Bellicius Firminus. Its location is in the public area provided by the city council.

Date: mid of the $3^{\text {rd }}$ century

(Kuzsinszky, 1937:pp.135-137; Póczy, 2004:p.254).

\section{Cat. 26:}

Location: Szentendre, the area of the Roman camp.

Imp(erator) Caes(ar) / [[M(arcus) Aureli/us]] Severus / [[Alexander]]/5 p(ius) f(elix) Augustus / pon(tifex) maxi / mus trib(unicia) / potest(ate) / [[VIII]] co(n)s(ul) [[III]] p(ater) p(atriae) /10 restituit / (A)q(uinco) m(ilia) p(assum) VIII

Emperor Caesar Marcus Aurelius Severus Alexander Pius Felix Augustus, High Priest, the eighth time tribune ruler, consul for the third time, the father of homeland has been restored (the road). 8 miles from Aquincum.

Limestone; height: 172; lower diameter: 43; upper diameter: 35

Date: 229. AD

CIL III 3738 (Fitz, 1993-1995:p.373; Nagy, 2007:p.144).

\section{Cat. 27:}

Imp(erator) Caes(ar)[M(arcus) Opellius] / Severus [Macrinus] pius Augus / tus co(n)s(ul) proco(n)sul tribunicia / potestate et [Ope] 1li[us Diad /5 um]enianus nobilissimus / Caesar vias et pontes ve / tustate corruptas res / tituerunt cura agente / [Aelio Tric]c[iano leg(ato) Aug(usti)] /10 pr(o)pr(aetore) ab / Aq(uinco) m(ilia) p(assuum) / II

To Emperor Caesar Marcus Opellius Severus Macrinus Pius Augustus, Consul, Proconsul of the Tribune, and the very noble Caesar Opellius Diadumenianus restored the roads and bridges that had collapsed due to their ancient condition. By the care of Aelius Ticcianus imperial legatus. Two thousand double steps from Aquincum. (Kuzsinszky, 1900:p.8).
Cat. 28:

Imp(eratori) Caes(ari) C(aius) / Iul(io) Ve[ro Maxi / mino] invicto / pio felici Aug(usto) / pontific(i) $\max (\mathrm{imo}) / 5$ trib(unicia) potestat(e) / $\mathrm{p}$ (atri) $\mathrm{p}$ (atriae) proconsul(i) / leg(io) II ad(iutrix) p(ia) f(idelis) [Ma / ximiniana ab] / Aq(uinco) /10 m(ilia) p(assum) / II

To Imperator Caesar Caius Iulius Verus Maximinus, the invincible Pius Felix Augustus, the high priest, vested with tribune authority, father of the home, proconsul, legio II Adiutrix Pia Fidelis Maximiniana. Two thousand double steps from Aquincum. (Kuzsinszky, 1900:p.9).

Cat. 29:

Imp(eratori) Caes(ari) C(aius) / Iul(io) [Vero Maxi / mino] invicto / p(io) f(elici) Aug(usto) pont(ifici) $/ 5 \max$ (imo) trib(unicia) potest(ate) / p(atri) p(atriae) co(n)s(uli) proconsul(i) / [et C(aius) Iul(io) Vero / Maximo] nobi / lissimo Caesari / leg(io) II ad(iutrix) p(ia) f(idelis) [Ma /10 ximiniana ab] Aq(uinco) / m(ilia) p(assuum) II

To Imperator Caesar Caius Iulius Verus Maximinus, the invincible Pius Felix Augustus, the high priest, vested with tribune authority, the father of the home, consul, proconsul, and to Caius Iulius Verus Maximus, the very noble Caesar, the legio II Adiutrix Pia Fidelis Maximiana. Two thousand double steps from Aquincum (Kuzsinszky, 1900:p.10).

Cat. 30:

Imp(eratori) Caes(ari) / M. Iul(io) Philippo / P(io) F(elici) invicto Aug(usto) / pont(ifici) maximo /5 Parthico maximo / trib(unicia) potest(ate) co(n)s(uli) / p(atri) p(atriae) proc(n)s(uli) et / M. Iul(io) Philippo / nobilissimo Caes(ari) /10 et Marciae Otaciliae / Severae sanctissimae / Aug(ustae) coniugi Aug(usti) n(ostri) / matri castrorum et / exercituus leg(io) II ad(iutrix) $/ 15 \mathrm{p}$ (ia) f(idelis) Philippiana devota / [n] umini maiestatique / eorum / [ab] Aq(uinco) m(ilia) p(assuum) / II

To the invincible Imperator Caesar Marcus Iulius Philippus Pius Felix Augustus, the high priest, the triumphant over the Parthians, vested with tribune authority, the consul, the father of the home, the proconsul and to the most noble Caesar Marcus Iulius Philippus and the Wife of Most Holy Augustus, the mother of the camp, Marcia Otacilia Severa. Legio II Adiutrix Pia Fidelis Philippiana devoted to their deity and majesty. Two thousand double steps from Aquincum (Kuzsinszky, 1900:p.11). 


\section{Appendix}

Table 1 Summary

\begin{tabular}{|c|c|c|c|c|c|c|c|}
\hline $\begin{array}{l}\text { Cat. } \\
\text { no. }\end{array}$ & Adorated to & Type of building & $\begin{array}{c}\text { Type of } \\
\text { construction }\end{array}$ & $\begin{array}{c}\text { Reason of } \\
\text { construction }\end{array}$ & $\begin{array}{l}\text { Type of the } \\
\text { covering }\end{array}$ & Constructor & $\begin{array}{l}\text { The date of } \\
\text { the panel's } \\
\text { installation }\end{array}$ \\
\hline 1. & & Fanum of Nemesis & $\begin{array}{c}\text { new } \\
\text { construction }\end{array}$ & & $\begin{array}{l}\text { private } \\
\text { budget }\end{array}$ & $\begin{array}{l}\text { Chrysantus } \\
\text { and Aemilius } \\
\text { Funatianus }\end{array}$ & \\
\hline 2. & & $\begin{array}{c}\text { Fanum of Dea Nemesis } \\
\text { Regina }\end{array}$ & $\begin{array}{c}\text { new } \\
\text { construction }\end{array}$ & & $\begin{array}{l}\text { private } \\
\text { budget }\end{array}$ & & \\
\hline 3. & $\begin{array}{l}\text { Nemesis Augusta } \\
\text { omnipotenti }\end{array}$ & fogadalmi oltárkő & & & $\begin{array}{l}\text { private } \\
\text { budget }\end{array}$ & & $\begin{array}{l}\text { Aug. 20, } \\
\text { 162. AD }\end{array}$ \\
\hline 4. & $\begin{array}{c}\text { Marcus Aurelius } \\
\text { Antoninus Augustus }\end{array}$ & Templum of Nemesis & reconstruction & $\begin{array}{l}\text { collapsed because } \\
\text { it was an old } \\
\text { construction } \\
\text { (vetustate } \\
\text { conlapsum) }\end{array}$ & $\begin{array}{l}\text { private } \\
\text { budget }\end{array}$ & $\begin{array}{l}\text { Aurelius Florus } \\
\text { and Mercator }\end{array}$ & $\begin{array}{l}\text { Jun. 24, } \\
\text { 214. AD. }\end{array}$ \\
\hline 5. & & inscripted stone & & & & $\begin{array}{c}\text { Pupilius } \\
\text { Hyliatianus }\end{array}$ & \\
\hline 6. & & $\begin{array}{l}\text { Templum of Dea Baltis } \\
\text { and Dea Syria }\end{array}$ & $\begin{array}{c}\text { new } \\
\text { construction }\end{array}$ & & $\begin{array}{l}\text { private } \\
\text { budget }\end{array}$ & Titus Flavius & $\begin{array}{c}\text { cc. } 3^{\text {rd }} \text { Century } \\
\text { AD }\end{array}$ \\
\hline 7. & $\begin{array}{c}\text { Imperator Caesar } \\
\text { Marcus Aurelius } \\
\text { Severus Antoninus and } \\
\text { Iulia Domna }\end{array}$ & $\begin{array}{c}\text { Sacrum / Templum of } \\
\text { Hercules }\end{array}$ & $\begin{array}{l}\text { restoration and } \\
\text { enlargement }\end{array}$ & $\begin{array}{l}\text { votive } \\
\text { (ex voto) }\end{array}$ & $\begin{array}{l}\text { private } \\
\text { budget }\end{array}$ & & 216. AD \\
\hline 8. & & $\begin{array}{c}\text { Templum of Iuppiter } \\
\text { Dolichenus }\end{array}$ & restoration & $\begin{array}{l}\text { collapsed because } \\
\text { it was an old } \\
\text { construction } \\
\text { (vetustate } \\
\text { conlapsum) }\end{array}$ & $\begin{array}{l}\text { imperial } \\
\text { budget }\end{array}$ & $\begin{array}{c}\text { Imperator } \\
\text { Lucius } \\
\text { Septimius } \\
\text { Severus } \\
\text { Augustus and } \\
\text { Imperator } \\
\text { Marcus } \\
\text { Aurelius } \\
\text { Antoninus } \\
\text { Augustus }\end{array}$ & 202. AD \\
\hline 9. & & $\begin{array}{l}\text { Templum of the genius } \\
\text { of the valetudinarium } \\
\text { of leg. II Adiutrix Pia } \\
\text { Fidelis Severiana }\end{array}$ & $\begin{array}{c}\text { new } \\
\text { construction }\end{array}$ & & $\begin{array}{l}\text { private } \\
\text { budget }\end{array}$ & Aurelius & 222-235. AD \\
\hline 10. & & Templum & restoration & $\begin{array}{l}\text { because of the } \\
\text { election for } \\
\text { augustalis }\end{array}$ & $\begin{array}{l}\text { private } \\
\text { budget }\end{array}$ & $\begin{array}{l}\text { Caius Cornelius } \\
\text { Corinthus }\end{array}$ & \\
\hline 11. & & Nymfeum (sic!) & $\begin{array}{c}\text { new } \\
\text { construction }\end{array}$ & & $\begin{array}{l}\text { private } \\
\text { budget }\end{array}$ & $\begin{array}{l}\text { Caius Titius } \\
\text { Antonius }\end{array}$ & cc. $200 . \mathrm{AD}$ \\
\hline 12. & & $\begin{array}{l}\text { balneum of leg. } \\
\text { II Adiutrix }\end{array}$ & $\begin{array}{c}\text { new } \\
\text { construction }\end{array}$ & & $\begin{array}{l}\text { imperial } \\
\text { budget }\end{array}$ & $\begin{array}{c}\text { Imperator } \\
\text { Caesar Marcus } \\
\text { Aurelius } \\
\text { Severus } \\
\text { Alexander }\end{array}$ & 222-235. AD \\
\hline 13. & & $\begin{array}{l}\text { larger baths of leg. } \\
\text { II. Adiutrix (thermae } \\
\text { maiores) }\end{array}$ & restoration & $\begin{array}{l}\text { it was not used for } \\
\text { a long time and } \\
\text { became abandoned } \\
\text { (magno tempore } \\
\text { intermissaa et } \\
\text { restitutae) }\end{array}$ & $\begin{array}{l}\text { imperial } \\
\text { budget }\end{array}$ & & $\begin{array}{l}\text { Jun. } 30 \\
\text { 268. AD }\end{array}$ \\
\hline 14. & & palaestra & & & & & \\
\hline 15. & $\begin{array}{c}\text { Imperator Caesar Titus } \\
\text { Aelius Antoninus } \\
\text { Augustus Pius }\end{array}$ & $\begin{array}{l}\text { amphitheatrum of the } \\
\text { military city }\end{array}$ & $\begin{array}{c}\text { new } \\
\text { construction }\end{array}$ & & $\begin{array}{l}\text { imperial } \\
\text { budget }\end{array}$ & $\begin{array}{l}\text { Legio II } \\
\text { Adiutrix }\end{array}$ & 145. AD \\
\hline
\end{tabular}




\begin{tabular}{|c|c|c|c|c|c|c|c|}
\hline $\begin{array}{l}\text { Cat. } \\
\text { no. }\end{array}$ & Adorated to & Type of building & $\begin{array}{c}\text { Type of } \\
\text { construction }\end{array}$ & $\begin{array}{l}\text { Reason of } \\
\text { construction }\end{array}$ & $\begin{array}{l}\text { Type of the } \\
\text { covering }\end{array}$ & Constructor & $\begin{array}{l}\text { The date of } \\
\text { the panel's } \\
\text { installation }\end{array}$ \\
\hline 16. & $\begin{array}{l}\text { Iuppiter Optimus } \\
\text { Maximus és Iuno } \\
\text { regina }\end{array}$ & $\begin{array}{l}\text { amphitheatrum of the } \\
\text { military city (gates) }\end{array}$ & restoration & & $\begin{array}{l}\text { private } \\
\text { budget }\end{array}$ & & \\
\hline 17. & & $\begin{array}{l}\text { amphitheatrum of the } \\
\text { military city (area of } \\
\text { the audiences) }\end{array}$ & restoration & & $\begin{array}{l}\text { private } \\
\text { budget }\end{array}$ & & \\
\hline 18. & & $\begin{array}{l}\text { amphitheatrum of } \\
\text { the civil town (sedile, } \\
\text { cathedra) }\end{array}$ & $\begin{array}{c}\text { new } \\
\text { construction }\end{array}$ & & $\begin{array}{l}\text { private } \\
\text { budget }\end{array}$ & $\begin{array}{l}\text { citizens of the } \\
\text { town }\end{array}$ & \\
\hline 19. & $\begin{array}{l}\text { császár üdvéért (a név } \\
\text { a feliart töredékessége } \\
\text { miatt bizonytalan) }\end{array}$ & basilica & $\begin{array}{l}\text { presumably new } \\
\text { construction }\end{array}$ & & & & \\
\hline 20. & & schola of collegium & reconstruction & & $\begin{array}{l}\text { private } \\
\text { budget }\end{array}$ & & \\
\hline 21. & Severus Alexander & cocinatorium & $\begin{array}{c}\text { new } \\
\text { construction }\end{array}$ & & $\begin{array}{l}\text { private } \\
\text { budget }\end{array}$ & $\begin{array}{l}\text { members of } \\
\text { the collegium } \\
\text { victorianorum }\end{array}$ & 223. AD \\
\hline 22. & & silanum & $\begin{array}{c}\text { new } \\
\text { construction }\end{array}$ & & $\begin{array}{l}\text { private } \\
\text { budget }\end{array}$ & $\begin{array}{l}\text { Caius Iulius } \\
\text { Severus }\end{array}$ & 201. AD \\
\hline 23. & & ornamentum & $\begin{array}{c}\text { new } \\
\text { construction }\end{array}$ & $\begin{array}{c}\text { as a donation (dono } \\
\text { dedit) }\end{array}$ & $\begin{array}{l}\text { private } \\
\text { budget }\end{array}$ & $\begin{array}{l}\text { Caius Titius } \\
\text { Antonius }\end{array}$ & $\begin{array}{l}\text { End of the } \\
2^{\text {nd }} \text { Century - } \\
\text { beginning of } \\
\text { the } 3^{\text {rd }} \text { century } \\
\text { AD }\end{array}$ \\
\hline 24. & & tabernac & reconstruction & $\begin{array}{l}\text { was in ruins } \\
\text { (venalium } \\
\text { remansorum) }\end{array}$ & $\begin{array}{l}\text { private } \\
\text { budget }\end{array}$ & $\begin{array}{l}\text { Titus Flavius } \\
\text { Fortio }\end{array}$ & $\begin{array}{l}\text { End of the } 2^{\text {nd }} \\
\text { Century AD }\end{array}$ \\
\hline 25. & $\begin{array}{l}\text { For the salvation of } \\
\text { Dea Syria, Dea Baltis } \\
\text { and the Emperor }\end{array}$ & $\begin{array}{c}\text { triumphal arch with } \\
\text { gate and covered with } \\
\text { ceramics }\end{array}$ & $\begin{array}{c}\text { new } \\
\text { construction }\end{array}$ & & $\begin{array}{l}\text { private } \\
\text { budget }\end{array}$ & $\begin{array}{l}\text { Caius Iulius } \\
\text { Sextinus }\end{array}$ & $\begin{array}{c}\text { Center of the } \\
3^{\text {rd }} \text { Century } \\
\text { AD }\end{array}$ \\
\hline 26. & & $\begin{array}{l}\text { milestone which } \\
\text { records a road } \\
\text { restoration }\end{array}$ & $\begin{array}{l}\text { reconstruction / } \\
\text { restoration }\end{array}$ & & $\begin{array}{l}\text { imperial } \\
\text { budget }\end{array}$ & $\begin{array}{c}\text { Imperator } \\
\text { Caesar Marcus } \\
\text { Aurelius } \\
\text { Severus } \\
\text { Alexander }\end{array}$ & 229. AD \\
\hline 27. & & $\begin{array}{l}\text { milestone which } \\
\text { records restoration of } \\
\text { roads and bridges }\end{array}$ & $\begin{array}{l}\text { reconstruction / } \\
\text { restoration }\end{array}$ & $\begin{array}{l}\text { were in bad } \\
\text { condition due to the } \\
\text { old status (vetustate } \\
\text { corruptas) }\end{array}$ & $\begin{array}{l}\text { imperial } \\
\text { budget }\end{array}$ & $\begin{array}{c}\text { Imperator } \\
\text { Caesar Marcus } \\
\text { Opellius } \\
\text { Severus } \\
\text { Macrinus Pius } \\
\text { Augustus } \\
\text { and Opellius } \\
\text { Diadumenianus }\end{array}$ & 217-218. AD \\
\hline 28. & $\begin{array}{l}\text { Caius Iulius Verus } \\
\text { Maximinus and Caius } \\
\text { Iulius Verus }\end{array}$ & milestone & $\begin{array}{c}\text { new } \\
\text { construction }\end{array}$ & & $\begin{array}{l}\text { imperial } \\
\text { budget }\end{array}$ & & \\
\hline 29. & $\begin{array}{l}\text { Caius Iulius Verus } \\
\text { Maximinus }\end{array}$ & milestone & $\begin{array}{c}\text { new } \\
\text { construction }\end{array}$ & & $\begin{array}{l}\text { imperial } \\
\text { budget }\end{array}$ & $\begin{array}{l}\text { Legio II } \\
\text { Adiutrix }\end{array}$ & 235-238. AD \\
\hline 30. & $\begin{array}{l}\text { Imperator Caesar } \\
\text { Marcus Iulius } \\
\text { Philippus, Marcus } \\
\text { Iulius Philippus } \\
\text { (Iunior) and Marcia } \\
\text { Otacilia Severa }\end{array}$ & milestone & $\begin{array}{c}\text { new } \\
\text { construction }\end{array}$ & & $\begin{array}{l}\text { imperial } \\
\text { budget }\end{array}$ & $\begin{array}{c}\text { Legio II } \\
\text { Adiutrix } \\
\text { Pia Fidelis } \\
\text { Philippiana }\end{array}$ & 244-249. AD \\
\hline
\end{tabular}

